\title{
Hydrogen Fuel Cells PEM
}

\section{Mahmoud Mohsen Ali Ahmad Alsayes, Khaled Hazem Hamed Ahmed}

Science Department, STEM High School for Boys, 6 Oct City, Giza, Egypt

\section{Email address:}

14135@stemegypt.edu.eg (M. M. A. A. Alsayes), 14045@stemegypt.edu.eg (K. H. H. Ahmed)

\section{To cite this article:}

Mahmoud Mohsen Ali Ahmad Alsayes, Khaled Hazem Hamed Ahmed. Hydrogen Fuel Cells PEM. Science Journal of Chemistry. Vol. 4, No. 4, 2016, pp. 49-52. doi: 10.11648/j.sjc.20160404.12

Received: May 31, 2016; Accepted: August 2, 2016; Published: August 31, 2016

\begin{abstract}
For centuries the Energy crisis has been a curse that made Egypt and the world suffer in various ways. Energy is the backbone of many aspects of life; yet depending on fossil fuel as the main source of energy has numerous drawbacks like the high price, transportation, unavailability and pollution to the environment. This has led us to assign the design requirement of having a cheap, available rather than green fuel for cars. As a result, our PEM hydrogen fuel cells are the solution to the problem after making essential changes in order to increase its efficiency while decreasing the price, through using nickel as a catalyst, instead of platinum. Finally, the test plan has assured that it meets the design requirements mentioned before, and unquestionably proved that our PEM fuel cells are the right and suitable solution for running vehicles.
\end{abstract}

Keywords: PEM Fuel Cell, Hydrogen, Metal Hydrides, Electric Cars

\section{Introduction}

Energy is an essential need for our life. It is the essential part of industry, transportation means and domestic uses which connects it to all other grand challenges. However, the energy production worldwide faces many issues, as about $81 \%$ of its production is from fossil fuel. Despite its high efficiency, it has many obstacles such as the increasing in prices, the possibility of running out in the near future, polluting the environment and the growing population demand. These problems have a considerable effect on Egypt because Egypt depends on fossil fuel in producing electricity, and this causes a shortage of 27, 700 megawatts (20\%) resulting in regular blackouts, especially, in summer. Egypt also suffer from gas and oil shortage used in domestic uses and vehicles. As a result, Egypt seeks to get energy from alternative resources like: hydro power in the high dam, solar energy stations in the western desert and using gasoline instead of oil in cars. Admittedly, each of the previous resources couldn't stand alone for the highly increasing population, so all of them were needed to complete each other and also have a sustainable future.

In our research, we have an objective which is achieving less pollutant rather than cheap car fuel by using the PEM hydrogen fuel cells. To reach this goal, we have to achieve some requirements such as being affordable by the public, dependable as the main energy source, and non-polluting to the environment. We modified the fuel cell prototype by using stainless-steel and nickel, instead of platinum, as catalyst which reduced the price significantly. And after testing the prototype, we found that it achieves these requirements and leads directly to make hydrogen "the fuel of the future".

\section{Review of Literature}

Fuel cells were first invented in the year 1839 by William grove which was called by him 'the gas battery'. Its idea of working was based on reversing the process of water electrolysis where the reaction of oxygen and hydrogen together form water and electricity these principles were demonstrated by Humphry Davy in 1801. In the 1970s the energy crisis arose and fossil fuel was threatened run out at any time. Moreover the awareness of how important was it to protect the environment from pollution increased which consequently increased the researches on alternative fuel resources which included the fuel cells. Then in 1980s the researchers developed the production of electricity of the fuel cell until it reached 100MW. In the 1990s attention was given to fuel cells due to its low cost and high production which lead to the developing of its usage in industrial and other fields specially solid oxide fuel cell (SOFC) and proton exchange membrane fuel cell (PEMFC) which lead into their 
use in vehicles (Jonathan Mathews, 2015).

Different types of fuel cells where made like: Proton Exchange Membrane Fuel Cell (PEM), Alkaline Fuel Cell (AFC), Phosphoric Acid Fuel Cell (PAFC), Molten Carbonate Fuel Cell (MCFC), Solid Oxide Fuel Cells (SOFC), Regenerative Fuel Cells (RFCs), Zinc Air Fuel Cells (ZAFCs), and Microbial Fuel Cells (MFCs), but PEM fuel cells where the most suitable one for cars and vehicles because it needed low operating temperatures. Consequently they were used by Honda in 2007 to make the first ever fuel cell car. However fuel cells had a significant problem which is the high price due to the use the expensive metal of platinum as a catalyst to separate the hydrogen atoms from each other as well as the oxygen atoms. so several researches where done to develop alternate catalysts these included the use of cobalt-graphene alloy and the use of nickel doped with manganese dioxide and the use of other metal oxides these researches lead us to use nickel presented in stainless alloy.

\section{Other Solutions Already Tried}

The current national energy supply mix in Egypt is:

- $95 \%$ from fossil fuel (petroleum products and natural gas)

- $5 \%$ from renewable resources (mainly hydro and wind, which is increasing gradually)

The electricity generation activity utilizes around 30\% of the fossil fuel and natural gas resources in addition to all the hydro and wind energy resources. The industrial activities in Egypt consume around $40 \%$ of the overall all energy available. The average annual increase of energy use has been around $6 \%$ over the last decade.

Producing electricity: its Current solution in Egypt is hydropower (the high dam), fossil fuel, and wind power, and its tried solution is using coal which didn't work because, coal produces more pollution than other fossil fuel and transporting it is very expensive relatively.

Running vehicles: its Current solution in Egypt is gasoline and natural gas, and its tried solution is vegetable oil, and coal which didn't work due to some technical problems in the engines.

Energy transformation: its Current solution in Egypt is wires (electricity), and Pipes and trucks for fluid fuels and its tried solution is trains for coal which didn't work because, they cause energy lose so we must work on getting with a special way to transport energy to reduce the lose energy.

\section{Design Requirements}

Cost: is one of the important design requirement in any project because, now Egypt suffers from an economic collapse. We have tried to reduce the cost of the hydrogen fuel cell by two major steps: First, we will use nickel in stead of platinum because, platinum is very expensive than gold it also not available in Egypt, while Nickel is very cheap, and available in Egypt.

Second, we will use gelatin instead of nafion as PEM
(Proton Exchange Membrane) because, nafion is very expensive that it costs $135 \$$ for the area of $30 \mathrm{~cm}^{\wedge} 2$, and gelatin membrane is made of potassium chloride, distilled water, and gelatin which are all cheap.

This design requirement can be tested by calculating the cost of our PEM fuel cell, and compering it with the cost of the typical one. It also can be tested by comparing the cost of $1 \mathrm{KW}$ that our PEM fuel cell produce, with the cost of amount of gasoline that produce the same amount of energy, or making a ratio between the cost, and the efficiency of our PEM fuel cell to compare it with the typical one.

Safety: We used the hydrogen sensor to make sure that there is no hydrogen leak to make the fuel cell more safety than before.

This design requirement can be tested by programing the Arduino with the hydrogen sensor to light a red led if there is a hydrogen leak, and putting the sensor in front of the hydrogen tank in different distances to determine the range of danger, and know the number of sensors that can insurance our car from the hydrogen leak

\section{Selection of Solution.}

Hydrogen fuel cell is way to solve over cars in gasoline stations, because we decided to create it for cars. As a result we won't use petroleum for cars again because petroleum makes a lot of problems in Egypt with high cost for example: pollution, economic problem, and car exhaust.

so we used hydrogen fuel cell for cars to solve all of these problems.

Cars in Egypt make a huge problems and there are no solutions until now for them, so we have searched for new researches in many international universities cites like (brown university cite) to know more about hydrogen fuel cell for cars.

Some basic information about hydrogen: hydrogen is the simplest element. An atom of hydrogen consists of only one proton and one electron. It's also the most plentiful element in the universe. Despite its simplicity and abundance, hydrogen doesn't occur naturally as a gas on the Earth - it's always combined with other elements. Water, for example, is a combination of hydrogen and oxygen $\left(\mathrm{H}_{2} \mathrm{O}\right)$.

Hydrogen is high in energy, yet an engine that burns pure hydrogen produces almost no pollution. NASA has used liquid hydrogen since the 1970s to propel the space shuttle and other rockets into orbit.

How does it work: a fuel cell is a device that generates electricity by a chemical reaction. Every fuel cell has two electrodes, one positive and one negative, called, respectively, the anode and cathode. The reactions that produce electricity take place at the electrodes.

Every fuel cell also has an electrolyte, which carries protons particles from one electrode to the other, and a catalyst, which speeds the reactions at the electrodes.

Hydrogen is the basic fuel, but fuel cells also require oxygen. One great appeal of fuel cells is that they generate electricity with no pollution, because all of the hydrogen and 
oxygen used in generating electricity ultimately combine to form a harmless byproduct, namely water.

How this solution meets our design requirements: the solution which we chose has many characteristic one of them is reducing the cost. We have used nickel instead of platinum because platinum is very expensive than gold, and it will represent a huge economic problem, if we achieve it in real life. Also platinum is not saving in Egypt. So we have chosen nickel as a solution for this problem, because it is very cheap, and available in Egypt, and for safety we used a hydrogen sensor to know if there is gas leaks (hydrogen) from the hydrogen tank to make the fuel cell more safety than before.

\section{Test Plan}

The first design requirements we chose to test was the cost of the prototype to make sure that it's affordable by the public and that we reduced the price of the watt relative to the typical PEM hydrogen fuel cell.

Another design requirement we tested was the safety of the prototype and this test was conducted to make sure that the prototype of the safety system was well operating.

I. Cost test plan:

Tools: multimeter - internet to determine costs of some materials

Objective: this requirement is to compare the price of our fuel cell and its power to those of the PEM fuel cell

Procedures:

1). Determine the prices and powers of our fuel cell and PEM fuel cell with platinum

2). set a ratio between fuel cell price to its power, after that we set another ratio between the price of the PEM fuel cell to its power

Success conditions: If the ratio in our fuel cell is less than the ratio in PEM fuel cells then it succeeded; otherwise, our fuel cell didn't meet the requirement.

II. Safety test plan

Tools: balloon filled with hydrogen - Arduino-LED hydrogen sensor - jumpers - ruler.

Objective: this test plan is to test the safety system in the prototype.

Procedures:

1). Pass an amount of hydrogen on the sensor from different distances.

2). If the LED lights then it detected hydrogen as warning to the passenger.

3). Graph the results of the effect of different distances on the hydrogen sensor.

Success conditions: If the led lit in the presence of hydrogen this indicates then the safety system is well operating, otherwise it needs some modifications.

\section{Methods}

We have used special materials that we associated together for forming the Hydrogen Fuel Cell prototype. These materials were $\left(2\right.$ pieces $\left(8 \times 4 \mathrm{~cm}^{2}\right)$ from Nickel used as a catalyst in the fuel cell, (5 gm of Gelatin, $38.5 \mathrm{gm}$ of Potassium Chloride, $80 \mathrm{ml}$ DI water) used for making the proton exchange membrane (PEM), 2 pieces $\left(8 \times 4 \mathrm{~cm}^{2}\right)$ from rubber are put in the prototype to prevent any hydrogen leakage, Arduino UNO used to program the hydrogen sensor, Hydrogen sensor used in the circuit to detect the presence of Hydrogen, 7 nuts with their bolts Used to fix pieces together, 4 jumpers Used to connect different parts of the circuit together, Bread board used as construction base for the sensor and other circuits parts, LED used in the circuit to light in the presence of hydrogen, and 2 Acrylic plastic sheets $\left(12.5 \times 9 \mathrm{~cm}^{2}\right)$ used to make the cover of the PEM fuel cell).

After the creation of our prototype we used it in two tests one of them was the Cost test plan: Tools: multimeter internet to determine costs of some materials.

Objective: this requirement is to compare the price of our fuel cell and its power to those of the PEM fuel cell

Procedures: Determining the prices and powers of our fuel cell and PEM fuel cell with platinum, then setting a ratio between fuel cell price to its power, after that we set another ratio between the price of the PEM fuel cell to its power.

Success conditions: If the ratio in our fuel cell is less than the ratio in PEM fuel Cells then it succeeded; otherwise, our fuel cell didn't meet the requirement.

The other was the Safety test plan: Tools: balloon filled with hydrogen - Arduino-LED - hydrogen sensor - jumpers - ruler.

Objective: this test plan is to test the safety system in the prototype.

Procedures: Passing an amount of hydrogen on the sensor from different distances, and observing the distance that the led don't light in, then graphing the results of the effect of different distances on the hydrogen sensor.

Success conditions: If the led lit in the presence of hydrogen this indicates then the safety system is well operating, otherwise it needs some modifications.

\section{Results}

After doing the coast test plan we founded that the total cost of raw material used in prototype $=$ (price of gelatin + price of stainless steel + price of rubber + price of nuts and bolts + price of potassium chloride + price of Distilled water + price of Acrylic sheets $)=8$ Pounds and it produces 0.3 $( \pm 0.02)$ volts and $0.225( \pm 0.031)$ watts.

An average fuel cell made of platinum costs about $700 \mathrm{~L} . \mathrm{E}$ and produces $0.6( \pm 0.1)$ volts and $0.9(0.32)$ watts

Cost to power ratio in our fuel cell $=x=\frac{\text { cost }}{\text { power }}=\frac{8}{0225}=$ 35.58 L.E/Watts

Cost to power ratio in PEM fuel cell (Using platinum) $=\frac{\text { cost }}{\text { power }}=\frac{700}{0.9}=777.78$ L.E $/$ Watts.

When we finished the safety test plan we made sure that our prototype is safe, because it can measure the danger of hydrogen leak until $20 \mathrm{~cm}( \pm 0.03 \mathrm{~cm})$ far from the hydrogen storage as shown in graph 5 so the distance between each sensor and the other will be $20 \mathrm{~cm}$. 


\section{Recommendations}

Catalysts: doing further researches on alternative catalysts used in the fuel cell as cobalt-graphene, which provide more efficiency because it has more unpaired electrons on its (d) sup-level which help it to make ponds with reactant. However; it is less expansive than platinum, and carbon Nano-tubes which increase the efficiency by $85 \%$. however; it also more cheaper than platinum.

Hydrogen storage: using metal hydrides in storage of hydrogen which proved in many researches to have high capacity with lower price made of simple material as Aluminum and stainless steel. This hydrides hosepipe is covered with Nano ceramic which prevents the hydrogen from leaking.

Electric loss: searching ways to reduce any electric loss by developing the concept of using super-conductors instead of using cupper, because the super-conductors can reach zero resistance.

Motors: the use of 90 volts electric DC motors which will be suitable to cars running on fuel cells and have lower price as brushless and induction motors.

Producing hydrogen: preforming further researches on new environmental ways to produce hydrogen used in fuel cells as Conversion of Biomass and Wastes, Solar Thermal Water Splitting.

\section{References}

[1] Problem 1. (2009). Retrieved February 10, 2015, from Hydrogen Storage - The Green Age. (n. d.). Retrieved March 6, $2015 \mathrm{http}: / / \mathrm{www}$.thegreenage.co.uk/tech/hydrogen-storage/

[2] Wilson, R. (2014, July 30). Which Countries Produce The Most Fossil Fuels? Retrieved February 10, 2015.

[3] The Hidden Cost of Fossil Fuels. (n. d.). Retrieved February $10,2015$.

[4] White, J. (2015, January 28). The Problem with Fossil Fuels. Retrieved February 11, 2015.
[5] Carpenter, M., Hoover, M., \& Benbow, A. (n. d.). Earth's Natural Resources. In Earth comm a project-based space and earth system science (Second ed., p. 729).

[6] Bouttes, J., Dassa, F., \& Crassous, R. (2011, September 12). Paris Tech Review. Retrieved February 22, 2015.

[7] Hussein, M. (2014, September 7). Renewable energy is Egypt's raft out of crisis: Experts. Retrieved.

[8] Press, A. (2014, May 2). Egypt in energy crisis as elections approach. Retrieved.

[9] What you need to know about energy. (n. d.). Retrieved February 22, 2015.

[10] Fuel Cell Vehicles. (n. d.). Retrieved March 6, 2015, from Fuel cells. (n. d.). Retrieved March 6, 2015.

[11] Hydrogen Storage - The Green Age. (n. d.). Retrieved March 6, 2015.

[12] Fuel Cells 2000. (n. d.). Retrieved March 9, 2015.

[13] 2015 Hyundai Tucson Fuel Cell | Hydrogen-Powered Vehicle | Hyundai. (n. d.). Retrieved April 1, 2015.

[14] Grot, S., \& Meltser, M. (1998, June 9). Patent US5763113 Proton exchange membrane. Retrieved April 2, 2015.

[15] Hydrogen Energy, a sustainable energy Planète hydrogène. (n. d.). Retrieved April 2, 2015.

[16] Hydrogen Fuel. (n. d.). Retrieved April 2, 2015.

[17] Collecting the History of Proton Exchange Membrane Fuel Cells. (2004, January 1). Retrieved April 3, 2015.

[18] Nove, R. (n. d.). Electrolysis of Water. Retrieved April 3, 2015.

[19] Duke University. (2013, May 21). Engineers devise new way to produce clean hydrogen. Science Daily. Retrieved April 3, 2015.

[20] Energy. (2009, March 24). Retrieved April 10, 2015.

[21] Vehicles have changed a lot. Their fuel? Not so much. (2013, May 16). Retrieved April 21, 2015. 